\title{
Sneaking Through the Backdoor - Reflections on Public Interest in International Investment Arbitration
}

\author{
by DR ANDREAS KULICK*
}

\section{INTRODUCTION}

We are becoming more and more familiar with a simple but seemingly convincible narrative of international investment law: It is powerful - it bestows non-State actors with international rights that bite, it provides for rather effective mechanisms of international adjudication and enforcement - but it neglects the public interest. ${ }^{1}$ Whether or not this is a laudable pattern is much disputed and for the sake of this contribution I will leave it at that. ${ }^{2}$ The oddity that international investment arbitration as well as Bilateral Investment Treaties (BITs) ${ }^{3}$ do not pay much attention to public interest concerns remains noteworthy nonetheless. As Gus van Harten ${ }^{4}$ has argued so forcefully, international investment arbitration exhibits most traits which characterize public law adjudication - above all, judicial control of the exercise of public authority and (public law) remedies for the abuse

* Andreas Kulick studied law in Freiburg, Geneva, Berlin and New York. He holds law degrees from Humboldt University Berlin (First State Exam 2008), New York University School of Law (LL.M. 2009), the University of Tübingen (Dr. iur. 201 l) and the State of Berlin (Second State Exam 2012). He is admitted to the Frankfurt Bar. Specializing in public international law and international arbitration, he is member of the arbitration team in the Paris office of an international law firm where he represents States and corporations in disputes before international courts and tribunals. This contribution expresses the author's personal opinion.

1 I will use 'public interest' as it is often used in international investment law literature as a broad term encompassing any legitimate regulatory interest a State is obligated to pursue or to promote under either domestic (constitutional) law or international law, cf. e.g. F. Baetens, 'Discrimination on the Basis of Nationality: Determining Likeness in Human Rights and Investment Law', in S.W. Schill (ed.), International Investment Law and Comparative Public Law 279 at $301 \mathrm{ff}$ (Oxford U. Press 2010).

2 For a case to include public interest in international investment law see A. Kulick, Global Public Interest in International Investment Law (Cambridge U. Press 2012).

3 There are some remarkable exceptions such as the Norwegian Draft of 2008 and the Canadian Model BIT. Moreover, the trend seems to move towards at least mentioning more public interest issues in BITs, cf. e.g. the US Model BIT 2004. However, such BITs rarely give them teeth but mostly refer to public interests as mere aspirations without any mandatory nature.

4 See G. Van Harten, Investment Treaty Arbitration and Public Law (Oxford U. Press 2007), particularly pp. 143 ff.; G. Van Harten and M. Loughlin, 'Investment Treaty Arbitration as a Species of Global Administrative Law', 17 Eur. J. Int'l L. 121 (2006). 
of such authority in the form of effectively enforceable damages. ${ }^{5}$ Hence, a public law (adjudication) system that does not pay much attention to public interest appears a strange fact. However, a widespread consensus does seem to exist that this is actually a fact. ${ }^{6}$ As the title suggests, I want to challenge that.

My conclusion from the analysis of selected investment arbitration case law will be the following: While on the surface, investment tribunals reject or even refuse to consider public law issues on the merits, those arguments reappear where it actually counts - on the level of compensation and damages. Tribunals do not grant much prominence to public interest considerations and arguments when discussing and measuring the amount of damages; in fact they hardly even mention them. Nevertheless, I will argue that by setting extremely high standards or otherwise considerably lowering the amount of damages or compensation, the arbitrators implicitly take strong account of the public interest at hand.

This article falls into three further parts. (I.). First, I will point at some rare occasions in which tribunals or (dissenting) arbitrators explicitly referred to public interest arguments in order to make their case (II.). Second, at the core of my contribution lies the analysis of selected investment arbitration case law dealing with public interest issues that follows the usual pattern, i.e. either explicitly rejecting or not mentioning public interest argumentation (III.). Third, the last section will amalgamate the results and seek to forge the conclusion that public interest considerations do actually play a role in international investment arbitration. Their existence is, however, a clandestine one. As it appears, as regards public interest, to the tribunals the action is not so much on the merits stage as rather on the level of compensation and damages. The doctrinal approach, however, needs considerable refinement (IV.).

\section{FORESHADOWING: EXPRESS REFERENGES TO PUBLIC INTEREST}

As mentioned above, occasions are very rare in which arbitration tribunals have referred to public interests explicitly in order to corroborate their argumentation. I will briefly discuss two cases, Himpurna v. $P L N^{\prime}$ and Ian Brownlie's Separate Opinion in CME v. Czech Republic. ${ }^{8}$

In Himpurna, PLN, an Indonesian State-owned electricity utility refused to fulfill its contractual obligations owed to the investor, since the 1997 Asian crisis had

\footnotetext{
5 Also see A. Kulick, Book Review: S.W. Schill (ed.), International Investment Law and Comparative Public Law, 22 Eur. J. Int'l L. 917 (201 1), and S.W. Schill, 'International Investment Law and Comparative Public Law - An Introduction', in S.W. Schill (ed.), International Investment Law and Comparative Public Law 3 (Oxford U. Press 2010). Against the notion of international investment law as public law see M. Hirsch, 'Investment Tribunals and Human Rights: Divergent Paths', in P.M. Dupuy, F. Francioni and E.U. Petersmann (eds.), Human Rights in International Investment Law and Arbitration (Oxford U. Press 2009), 97, 107 ff. and my counter-arguments in Kulick, 922.

6 See instead of many van Harten, supra n. 4, $149 \mathrm{ff}$.

7 Himpurna California Energy Ltd v. PT (Persero) Perusahaan Listruik Negara (PLN), Final Award, 4 May 1999, Yearbook of Commercial Arbitration XXV (2000), 13 (hereinafter: Himpurna v. PLM).

8 CME Czech Republic B.V. (The Netherlands) v. Czech Republic, UNCITRAL, Final Award, Separate Opinion by Ian Brownlie, 14 Mar. 2003 (hereinafter: CME v. Czech Republic, Separate Opinion Brownlie).
} 
made the contract economically unviable. According to the investment contract, Himpurna was required to develop a geothermal energy facility in Indonesia by making large investments into the sector and PLN had to purchase electricity generated from the project. Although the issue came before an international commercial arbitration forum, the legal questions involved were essentially those typically to be found in investment arbitration.

In the eyes of the Tribunal, while the crisis could not justify the breach, the investor's entitlement to lucrum cessans was considerably limited for, so the arbitrators held, claiming the full amount of lost profits would have constituted an abuse of rights:

'The respondent did not seek actively to dispossess the claimant of valuable contractual rights; it has suffered helplessly from a precipitate deterioration in the macroeconomic value of the project with respect to which it had accepted the entire market risk.

$[\ldots]$

[T] he issue of lucrum cessans has so often come up in the context of cases where the defending State entity has acted to evict the foreign investor from a healthy on-going profitable venture. Thus the notion of the victim's lost profits has gone hand in glove with that of the breaching party's gain.'

In contrast to the latter scenario, the Tribunal found that in the present case Indonesia - through PLN - did not intend to enrich itself by appropriating Himpurna's benefits and hence the Tribunal concluded that this fact must have a 'moderating effect' on the recovery of lucrum cessans. ${ }^{10}$ In other words, the Himpurna Tribunal emphasized the limiting influence of the crisis and the pressure that thus was put on the host State on the calculation of compensation and damages.

Along those lines, in CME v. Czech Republic Professor Brownlie acknowledged the distinct challenges that a modern welfare State has to face, which owes myriads of obligations to its citizens in this regard. In his Separate Opinion Ian Brownlie argued that:

'[a]ny assessment of the commercial approach to compensation in these proceedings must involve an adequate appreciation of the character of a bilateral investment treaty. [...]

In this context, it is simply unacceptable to insist that the subject-matter is exclusively commercial in character or that the interests at issue are, more or less, those of the investor. Such an approach involves setting aside a number of essential elements in a Treaty relation. The first element is the significance of the fact that the Respondent is a sovereign State, which is responsible for the well-being of its people. This is not to confer a privilege on the Czech Republic but only to recognize its special character and responsibilities. The Czech Republic is not a commercial entity.

[...]

The resources of a corporation entail considerable flexibility in changing the location of assets and in changing the organization of assets. The resources of a country, its human and natural resources, are a given: they are necessarily fixed.' 11

9 Himpurna v. $P L \mathcal{N}$, p. 93, para. 332 and p. 94, para. 335.

10 Ibid., p. 96 , para. 342.

$11 \quad C M E$ v. Czech Republic, Separate Opinion Brownlie, para. 73, 74 and 76. 
Thus, in Brownlie's opinion, such limited flexibility is due to the host State's special role as a sovereign entity obligated to serve the wellbeing of its citizens. He maintained that such role requires a careful balancing of the investor's interest with the interest of the host State, which represents the interest of its population and rests on considerations of fairness that must find reflection in the eventual calculation of compensation and damages. ${ }^{12,13}$ The thrust of this argumentation is quite forceful. So far, however, it has remained a lonely voice in investment arbitration practice. ${ }^{14}$

\section{THREE CASES}

The three cases I have chosen for my analysis below, naturally, are a selection. As selections go, they might not fully reflect and capture all aspects of a topic. However, I deem these cases representative of the pattern that a broader and more widespread analysis exhibits. ${ }^{15}$

(a) Azurix v. Argentina ${ }^{16}$

\section{(i) Facts, issues and the Tribunal's decision}

In 1999, American corporation Azurix, an Enron spin-off, won the bid for a thirty-year concession to run the water and sewage systems in the Argentine province of Buenos Aires paying United States Dollars (USD) 438.6 million as a so-called canon payment. ${ }^{17}$ By March 2000, customers complained about very low

12 Ibid., paras 72 and 79. Furthermore, Brownlie notes the extremely high amount of compensation granted (more than USD 500 million) in relation to the Czech Republic's annual GDP (about USD 54 billion). With thus the damages amounting to $1 \%$ of the Czech's Republic annual GDP, Brownlie asserts by reference to the Gulf of Maine case (Canada v. United States), ICJ Reports 1984, p. 342, para. 237, that signing a BIT must not result in liabilities 'likely to entail catastrophic repercussions for the livelihood and economic well-being of the population'. Also cf. S. Ripinsky and K. Williams, Damages in International Investment Law (British Institute of International and Comparative Law, 2008), 357.

13 Also note Southem Pacific Properties (Middle East) Limited v. Arab Republic of Egypt (ICSID Case No. ARB/84/3), Award, 20 May 1992, 3 ICSID Reports (1992), 189, para. 190 f., holding that the fact that the Claimant's business activities would have become internationally unlawful starting from the date of Egypt ratifying the UNESCO World Cultural Heritage Convention 'had 'significant consequences' in terms of determining the quantum of compensation.' See L. Liberti, 'The Relevance of Non-Investment Treaty Obligations in Assessing Compensation', in P.M. Dupuy, F. Francioni and E.U. Petersmann (eds.), Human Rights in International Investment Law and Arbitration (Oxford U. Press 2009), 557 at $562 \mathrm{ff}$. On the said UNESCO Convention see Convention Concerning the Protection of the World Cultural and Natural Heritage, Adopted in Paris, 16 Nov. 1972, available at http://whc.unesco.org/en/conventiontext.

14 Not to mention that the majority in $C M E$ did not join Professor Brownlie's arguments.

15 For such analysis, I refer to the three last chapters of my recent book, dealing with the environment, human rights and the combat against corruption in international investment case law, see A. Kulick, supra n. 2.

16 Azurix Corp v. Argentina, ICSID Case No. ARB/01/12, Award, 14 Jul. 2006 (hereinafter: Azurix v. Argentina). The dispute stretches over a considerable time period resulting in an (however, dismissed) application on annulment of the original award, see Azurix Corp v. Argentina, ICSID Case No. ARB/01/12, Decision on the Application for Annulment of the Argentine Republic, 1 Sep. 2009. However, the ad hoc Committee's decision deals with issues not particularly relevant to our analysis beforehand and thus I consider it a venial sin not to further elaborate on the Azurix annulment award. 
water pressure. Moreover, half a million people's local water supply was intoxicated by bacteria. Customers were advised by authorities to boil tap water, to minimize exposure to water and not to pay their water bills. Eventually, Azurix terminated the Concession Contract in October 2001. ${ }^{18}$ The Tribunal summarizeed the issues and claims introduced by the parties as follows:

\begin{abstract}
'The Claimant contends that its investment in Argentina has been expropriated by measures of the Respondent tantamount to expropriation and that the Respondent has, in addition, violated its [BIT] obligations [ ... ] of fair and equitable treatment, non-discrimination and full protection and security; that such measures are actions or omissions of the Province or its instrumentalities that resulted in the non application of the tariff regime of the Concession for political reasons; that the Province did not complete certain works that were to remedy historical problems and were to be transferred to the Concessionaire upon completion; that the lack of support for the concession regime prevented ABA [Azurix' subsidiary] from obtaining financing for its Five Year Plan; that in 2001, the Province denied that the canon was recoverable through tariffs; and that 'political concerns were always privileged over the financial integrity of the Concession', and '[w]ith no hope of recovering its investments in the politicized regulatory scheme, ABA gave notice of termination of the Concession and was forced to file for bankruptcy'.

The Respondent has disputed the allegations of the Claimant. For the Respondent, the dispute is a contractual dispute and the difficulties encountered by the Concessionaire in the Province were of its own making. In particular, the Respondent has argued that the case presented by the Glaimant is intimately linked to Enron's business practices and its bankruptcy; that the price paid for the Concession was excessive and opportunistic and related to the forthcoming IPO of Azurix at the time Azurix bid for the Concession [...] and that the Concessionaire did not comply with the Concession Agreement, in particular its investment obligations, and the actions of the Province, including the termination of the Concession Agreement by the Province, were justified. . $^{19}$
\end{abstract}

Azurix claimed USD 550 million in compensation alleging, inter alia, expropriation and failure to provide fair and equitable treatment.

The Tribunal's view is adequately summarized in its following statement: 'The Tribunal understands that governments have to be vigilant and protect the public health of their citizens but the statements and actions of the provincial authorities contributed to the crisis rather than assisted in solving it. ${ }^{\prime 20}$ The Tribunal found that Argentina's actions did not amount to an expropriation, ${ }^{21}$ for by applying a proportionality analysis in the assessment of whether an expropriation had actually occurred as done in Tecmed,,$^{22}$ the arbitrators opined that the degree of impact suffered by Azurix did not pass the relevant threshold in order to be regarded as expropriatory. ${ }^{23}$ Furthermore, the Tribunal held that Argentina did not provide fair and equitable treatment, since it engaged in political interference

18 P. Thielbörger, 'The Human Right to Water Versus Investor Rights: Double-Dilemma or Pseudo-Conflict:", in P.M. Dupuy, F. Francioni and E.U. Petersmann (eds.), Human Rights in International Investment Law and Arbitration 487, 496 (Oxford U. Press 2009).

19 Azurix v. Argentina, para. $43 \mathrm{f}$.

20 Ibid., para. 144.

21 Ibid., para. 322.

22 Tecnicas Medioambientales Tecmed S.A. v. The United Mexican States, ICSID Case No. ARB (AF)/00/2, Award, 29 May 2003, para. 122.

23 Azurix v. Argentina, para. 322. 
with the tariff régime and failed to complete the repairs that would have been required to avoid the intoxication of the water in the first place. ${ }^{24}$

The Tribunal granted compensation in the amount of the fair market value of the concession, ${ }^{25}$ however, it refrained from allowing Azurix to recover the entire canon payment of USD 438.6 million. Instead, it decided that the canon payment should not be considered recoverable through periodic tariff increases. Rather, in the Tribunal's view, it was upon the investor to make the appropriate calculation as to the expected earning stream and to bid for the concession accordingly. In the words of the Tribunal:

' $[N]$ o well-informed investor, in March 2002, would have paid for the Concession the price (and more particularly, the Canon) paid by Azurix in mid1999, irrespective of the actions taken by the Province and of the economic situation of Argentina at that time.'26

Nonetheless, the Tribunal stressed also Argentina's responsibility as to the loss in value of Azurix' investment. ${ }^{27}$

\section{(ii) Concealed relevance}

There are two aspects of the Tribunal's decision relevant for the analysis at hand. First, in its assessment of proportionality according to the Tecmed standard ${ }^{28}$ the arbitrators could have easily referred to the right to water, e.g. the State's obligation to provide affordable access to clean water, ${ }^{29}$ as a factor to be considered in the balancing exercise of the proportionality stricto sensu. ${ }^{30}$ Admittedly, the Tribunal underlined the public interest implications of the dispute as a general matter. However, it shied away from undertaking a detailed balancing exercise where it would have been compelled to become more precise but instead came to its conclusion merely after a very cursory glance at the factors involved..$^{31}$

The second issue worth mentioning is the arbitrators' reasoning vis-à-vis compensation. The Tribunal held that Azurix merely was entitled to fair market value of the investment and thus could not retain the entire canon payment it had paid in order to obtain the concession. According to the arbitrators, a reasonable businessman could not have expected to recuperate the whole sum but merely a small fraction of the canon payment given the tariff policy agreed upon by Azurix

\footnotetext{
Ibid., para. 376.

Ibid., para. 424.

Ibid., para. 426 .

Ibid., para. 428.

See supra $n .22$.
}

29 See General Comment No. 15, UN Doc. E/C 12/2002/l 1 of 26 Nov. 2002, UN Committee on Economic Social and Cultural Rights, available at http://www.unhchr.ch/tbs/doc.nsf/0/a5458dldlbbd713fcl 2 $56 \mathrm{cc} 400389 \mathrm{e} 94$ ? Open document, para. 12 (c)(ii). On the right to water in general and its relations to international investment law see Thielbörger, supra n. 18, 487.

On proportionality in international investment law see the excellent piece of B. Kingsbury \& S.W. Schill, 'Public Law Concepts to Balance Investor's Rights with State Regulatory Actions in the Public Interest - the Concept of Proportionality, in S.W. Schill (ed.), International Investment Law and Comparative Public Law 75(Oxford U. Press 2010).

31 Cf. also Thielbörger, supra n. 18, at 498 
and Argentina in the Concession Contract: ' $[\mathrm{N}] \mathrm{o}$ well-informed investor [...] would have paid for the Concession the price (and more particularly, the Canon) paid by Azurix. ${ }^{32}$ Arguably, the tribunal thus implicitly applied a core principle inhering the right to water, i.e. the right to affordable access to water for everyone. ${ }^{33}$ It involves that States must ensure that water prices stay at an affordable level even if a private operator provides the water services and hence must adopt necessary measures, including appropriate pricing policies. ${ }^{34}$ Holding that Azurix could not expect recuperating the entire canon payment, the Azurix tribunal arguably followed the rationale that water tariffs had to remain below a certain threshold and thus could not be considered to fully amortize the price paid for the investment. Hence it appears that the Tribunal implicitly endorsed the right to water as an argumentative topos in its assessment of compensation to be granted to the investor. ${ }^{35}$

\section{(b) Biwater v. Tanzania ${ }^{36}$}

\section{(i) Facts and issues}

The dispute roots in an intricate and highly complex factual matrix. In 2003, the Republic of Tanzania was awarded World Bank, African Development Bank and European Investment Bank loans in the amount of USD 140 million for the purpose of commissioning a comprehensive programme of repairs and upgrades to, and the expansion of, what was called 'the Dar es Salaam Water and Sewerage Infrastructure: the Dar es Salaam Water Supply and Sanitation Project'.37 As a condition of the funding, the three development banks obliged Tanzania to appoint a private operator to manage and operate the water and sewerage system and carry out some of the works associated with the Project. ${ }^{38}$

The government therefore invited tenders for the project in 2002 and eventually chose Biwater Gauff Tanzania (BGT) to execute it. Biwater, a British company, held $80 \%$ and Gauff, a German company, held $20 \%$ of the shares in their joint venture BGT. ${ }^{39}$ Moreover, Biwater and Gauff incorporated City Water Services Limited (City Water) under the laws of Tanzania on 17 December 2002, as the company operating the water and sewerage infrastructure. At the time of the proceedings, BGT held $51 \%$ of the shares in City Water, and Super Doll Trailer Manufacture Co. Ltd (STM), a Tanzanian company, held the remaining $49 \%{ }^{40}$

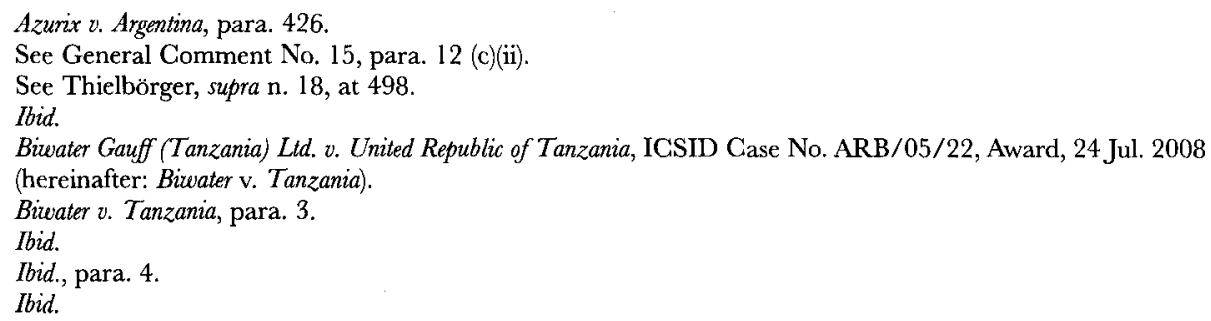


City Water, as the operating company, entered into three key contracts for the implementation of the Project with the Dar es Salaam Water and Sewerage Authority (DAWASA) on 19 February 2003, including, inter alia, the Water and Sewerage Lease Contract.

The incidents leading to the dispute started to unfold when City Water failed to considerably improve the dire water supply situation in Dar es Salaam, even taking into account DAWASA's prior failures and shortcomings. ${ }^{41}$ Additionally, City Water experienced serious financial distress due to miscalculations, performance shortcomings and considerably lower tariff collections compared with DAWASA's prior to the takeover by Gity Water. ${ }^{42}$ Regarding the subsequent events, the tribunal elaborates:

'Between 13 May 2005 and 1 June 2005, a series of events took place which, according to BGT, constituted breaches by the Republic of its obligations under international and domestic law. By way of overview:

- on 13 May 2005, the Minister of Water and Livestock Development purported to terminate the Lease Contract;

- on 16 May 2005, a call was made on the entire amount of the Performance Bond

- established by City Water in connection with the Lease Contract;

- on 17 May 2005, DAWASA issued a cure notice for the reinstatement of the Performance Bond under Article 50.1 of the Lease Contract;

- on 24 May 2005, the Tanzania Revenue Authority withdrew a VAT exemption;

- on 25 May 2005, DAWASA issued a Notice to Terminate under Article 51.3 of the Lease Contract, on the ground of failure to remedy the alleged breach notified in the cure notice of 17 May 2005; and finally

- on 1 June 2005, City Water's senior management were deported, and representatives of the Republic and DAWASA seized the company's assets, installed a new management (representatives of DAWASCO, a newly formed Government entity) and took over City Water's business. ${ }^{33}$

In the following arbitration before the International Centre for the Settlement of Investment Disputes (ICSID), Biwater and Gauff jointly claimed violation of their right to fair and equitable treatment as well as prompt, adequate and effective compensation upon alleged expropriation under the Agreement between the United Kingdom of Great Britain and Northern Ireland and the United Republic of Tanzania for the Promotion and Protection of Investments of 2 August 1996. ${ }^{44}$

\footnotetext{
Ibid, para. 147.

Ibid., para. 178

Ibid., para. 15.

Ibid., para. 16.
} 


\section{(ii) Amicable towards environmental issues - but not explicitly so}

While deciding on the viability of amicus curiae $e^{45}$ briefs, the Tribunal stated that it '[was] mandated to resolve claims as between BGT and the Republic, but also recognized that this arbitration raise[d] a number of issues of concern to the wider community in Tanzania. ${ }^{36}$ Having been admitted to set out their opinions, however without being granted access to the parties' submissions, the amici underlined that the environmental issues the dispute entailed required the investors to meet 'the highest level of responsibility to meet their duties and obligations as foreign investors before seeking protection under international law'. According to the amici, the investors' breach of their responsibility was to be found in their miscalculations and other shortcomings ${ }^{47}$ for given the importance of their investment for the population from an environmental perspective they should have acted with due diligence in order to warrant the water supply. ${ }^{48}$ In a nutshell, the amici argued: The higher the public interest concerns, the higher the threshold the investor has to pass in order to claim compensation.

In the beginning of the Tribunal's subsequent analysis it seems to prove immune to the amici's reasoning: BGT succeeded with its claim regarding the breach of the expropriation clause of the UK-Tanzania BIT. ${ }^{49}$ However, and here comes the intriguing part of the award, BGT eventually was not awarded any kind of compensation for the Tribunal declined to find for any monetary losses caused by the aforementioned violations. ${ }^{50}$ According to the arbitrators, the damages and financial setbacks from which BGT suffered were due to their own miscalculations and thus BGT's investment already was lacking any economic value when its rights under the BIT were violated.

Considering this finding, it appears the Tribunal proved much more sympathetic to the amici's allegations than it was ready to admit. It is notable that the standard for causation, derived from a thorough analysis of established customary international law rules, played out to be applied very strictly - one might say much more strictly than one might have anticipated. ${ }^{51}$ Though it did refrain from making any specific reference to the environmental issues involved, it is hard to ignore that there remains a distinct flavour of the acknowledged public interest concerns as the actually driving force in the Tribunal's considerations - at

45 On amicus curiae briefs in general as practiced under the Anglo-American doctrine see S. Krislov, 'The Amicus Curiae Brief: From Friendship to Advocacy', Yale L. J. 72 (1962-1963), 694; G. A. Caldeira and J. R. Wright, 'Amici Curiae before the Supreme Court: Who Participates, When, and How Much?', 52 J. of Pol. 782 (1990). Biwater $v$. Tanzania., para. 358. To corroborate its point, the tribunal also cited the Methanex dictum: 'there is an undoubtedly public interest in this arbitration.' See Methanex Corporation v. United States of America, UNCITRAL (NAFTA), Final Award, 3 Aug. 2005, para. 141.

47 See Bizeater v. Tanzania., para. 358.

48 Biwater $v$. Tanzania, para. $380 \mathrm{f}$.

49 Ibid., para. 519.

$50 \quad$ Ibid., para. 807.

51 See ibid., para. $790 \mathrm{ff}$. 
least as regards the standard-setting for causation of compensation and its application. ${ }^{52}$

(c) Glamis v. US $S^{53}$

\section{(i) Facts, issues and the Tribunal's findings}

Glamis Gold, Ltd. 'was a publicly held Canadian corporation engaged in the exploration, development and extraction of precious metals in the United States and Latin America'54 that, in 2006, merged with another Canadian company named Goldcorp, Inc. Starting from 1987, through its US subsidiary, Glamis had been acquiring mining claims and mill sites in the Imperial Desert in Southeastern California and attained full ownership of what it called 'The Imperial Project' site in 1994. According to the factual summary,

'[t]hrough open-pit mining techniques, [Glamis] planned to mine gold and silver with the expectation of removing 150 million tons of ore, and 300 million tons of waste rock, from three large open pits during the Project's projected 19-year life (from 1998 to 2017).55

The regulatory landscape in which mining developers have to manoeuvre in California is highly complex. However, three statutes may be identified as the most relevant relating to the dispute at hand: First, the 1872 Mining Law bestows any US citizen with the right to enter federal public lands and acquire ownership of a limited area of land, if he or she is able to prove the valuable and marketable discovery of hardrock minerals. Second, the 1976 Federal Law Policy and Management Act enables the US Department of the Interior to impose and to manage specific protections regarding the federal public land within the California Desert Conservation Area (CDCAA), a zone created by the Act and designed to preserve areas of significant scenic and biological importance and surrounding the Imperial Project site. ${ }^{56}$ The Bureau of Land Management (BLM) is competent to prepare and implement a comprehensive plan for operation, development and protection of the public land. ${ }^{57}$ Third, according to the California Desert Protection Act of 1994 (CDPA) mining or development is prohibited on a vast area in the neighbourhood of the Imperial Project. ${ }^{58}$

Glamis claimed to have been assured by BLM, which approved the Project in 1996, that its investment would remain 'comfortably outside of the wilderness areas

52 See ibid., para. $787 \mathrm{ff}$.

53 Glamis Gold, Ltd. v. United States of America, Award, 8 Jun. 2009, NAFTA, available at http://www.state.gov/ s/1/c10986.htm (hereinafter: Glamis v. US).

54 Glamis v. US, Memorial of Claimant Glamis Gold, Ltd., para. 19.

55 Glamis v. US, para. 33.

56 Ibid., paras. 41 to 43. Also cf. J. Cantegreil, 'Implementing Human Rights in the NAFTA Regime - The Potential of a Pending Case: Glamis Corp i. USA', in P.M. Dupuy, F. Francioni and E.U. Petersmann (eds.), Human Rights in Intermational Investment Law and Arbitration 367 at 371 (Oxford U. Press 2009).

57 Ibid.

58 Glamis v. US, para. $65 \mathrm{ff}$. 
designated by the CDPA.59 However, the Quechuan Indian Nation, the organization representing the indigenous Indian tribe of the Quechuans would soon intervene and allege that the Imperial Project's proximity to its sacred ancestral sites would put their spiritual and ceremonial practices in grave peril, by which they use to transmit their culture to new generations. ${ }^{60}$ According to their Non-Party Supplemental Submission, the Quechuans claimed that, inter alia, due to several provisions of the International Covenant on Civil and Political Rights (ICCPR) as well as the UN Declaration on the Rights of Indigenous Peoples ${ }^{61}$ the Imperial Project could not be executed. ${ }^{62}$ Thus, in January 2001, the BLM reversed its decision and the US Secretary of the Interior denied the mining permit. Moreover, subsequently, the California legislature adopted several additional measures that Glamis later on asserted as having further obstructed its investment. ${ }^{63}$ On 9 December 2003, Glamis filed a Notice of Arbitration against the United States under Chapter Eleven of the North American Free Trade Agreement (NAFTA), 'claim[ing] that the United States, through both the federal and state actions, expropriated Glamis' mining rights in violation of Article 1110 of the NAFTA and that the United States, through both the federal and state actions, denied Glamis the fair and equitable treatment required by Article 1105 of the NAFTA. 64

In turn, the Quechuans countered in their Non-party Supplemental Submission that:

\begin{abstract}
'under NAFTA Article 1131(1) [providing that a Tribunal adjudicating a claim under Chapter 11 'shall decide the issues in dispute in accordance with [the NAFTA] and applicable rules of international law'], the Tribunal is required to be mindful of how it construes the provisions at issue in this claim, Articles 1105 and I I 10, so that they do not require or authorize State conduct of the kind that would conflict with international norms protecting indigenous people generally, and the citizens of the Quechan Tribe in particular. Such an approach is the only way to ensure consistency in wider public international law and is also mandated in the customary international law rules on treaty interpretation, as restated in Article 31(3)(c) of the Vienna Convention on the Law of Treaties. ${ }^{165}$
\end{abstract}

The Tribunal, in a very elaborate and lengthy award comprising 362 pages eventually found no violation of the NAFTA, neither of the expropriation nor of the minimum standard of treatment clauses. As to Article 1110 (expropriation), it held that Glamis' investment was not rendered substantially without value by the

59 Glamis v. US, Notice of Arbitration, para. 6

60 Glamis v. US, Counter-Memorial of Respondent United States of America, paras. 50 ff.; Glamis v. US, Non-Party Supplemental Submission of the Quechuan Indian Nation, p. 1.

61 UN Declaration on the Rights of Indigenous Peoples, UN GA Res. 61/295, 13 Sep. 2007, available at http ://issuu.com/karinzylsaw/docs/un_declaration_rights_indigenous_peoples?mode=embed\&layout=http $\% 3$ A $\% 2 F \% 2 F$ skin.issuu.com $\% 2 F v \% 2 F$ dark\%2Flayout.xml\&showFlipBtn=true.

62 Ibid., p. $5 \mathrm{f}$.

63 Cantegreil, supra n. 56, 372.

64 Glamis v. US, para. 11.

65 Glamis v. US, Non-Party Supplemental Submission of the Quechuan Indian Nation, p. 8 (emphasis in the original). 
measures adopted by the US government and the Californian legislature. ${ }^{66}$ In its view

'the first factor in any expropriation analysis is not met: the complained of measures did not cause a sufficient economic impact to the Imperial Project to effect an expropriation of Glamis' investment. ${ }^{367}$

Furthermore, the Tribunal also stroke down Glamis' claim regarding a breach of the international minimum standard enshrined in NAFTA Article 1105. Defining the crucial threshold along the lines of the 1926 Neer case, ${ }^{68}$ the Tribunal did not see any grounds for the adopted measures and legislation violating the said standard. Rather, it opined that given the location of the Imperial Project next to the CDCA and in the proximity of the Quechuan Indians, Glamis was not entitled to compensation for the BLM revising its decision and the subsequent measures by the US Department of the Interior and the California State legislature ${ }^{69}$ However, the Tribunal expressly declined to consider the human rights arguments as brought forward by the Quechuan Indian Nation.

\section{(ii) A different solution}

When reading the Glamis award, it stands out that the extremely long decision never directly addresses human rights or other public interest considerations per se. Admittedly, elaborate passages, particularly vis-à-vis the Claimants' allegations regarding the international minimum standard in Article 1105 of the NAFTA, deal with the US and California measures targeted at protecting the interests of the Quechuan Indians. However, the tribunal treats them as any other legislation or administrative decisions the effect of which it has to consider in light of NAFTA Chapter 11. It does not even mention, let alone assess the validity or viability of human rights provisions or soft law instruments such as the ICCPR or the UN Declaration on the Rights of Indigenous Peoples. In other words, what the tribunal seems to implicitly convey is that human rights arguments may exclusively ground in domestic legislation, but lack applicability - despite the quite broad wording of NAFTA Article 1131 (1) - as an international law claim. Such limitation to domestic law, however, basically means to marginalize human rights considerations as an independent argumentative topos: For the tribunal, the content of the measure itself - the public interest, i.e. in the present case the human and minority rights considerations - was rather irrelevant. What interested the tribunal, was exclusively the question whether the measures adopted by the host State met the conditions as set forth in the Neer case, i.e. amount to an 'outrage, to bad faith, to wilful neglect of duty, or to an insufficiency of governmental action so

66 Glamis v. US, paras. $328 \mathrm{ff}$.

67 Ibid., para. 17 citing to paras. 534 to 536.

68 Neer v. Mexico, 15 Oct. 1926, 4 R. Int'l Arb. Awards, 60.

69 Ibid., para. $824 \mathrm{ff}$. 
far short of international standards that every reasonable and impartial man would readily recognize its insufficiency. ${ }^{30}$

Hence, myopia vis-à-vis human rights allegations? It appears so - at least at first glance. However, what is peculiar - and the Tribunal did not entirely succeed in extinguishing such smack of peculiarity - is that the Tribunal chose to step back to the Neer case of 1926 without accepting any other development having occurred since as the customary international law minimum standard of treatment and applying the Neer principles so strictly in the case at hand. True enough, NAFTA tribunals have been more cautious regarding the interpretation of Article 1105 NAFTA after the Commission interpretation of 2001 ensuing the broad Metalclad holding. ${ }^{71}$ Nonetheless, the limitedness and strictness with which the Tribunal chose to apply Article 1105 NAFTA is remarkable. While there is no express indication in the Glamis award and thus any consideration in this regard remains in the sphere of speculation, it does not seem entirely far-fetched that the Quechuan's cultural and ritual heritage at stake influenced the Tribunal's initial standardsetting.

\section{CONGLUSION: SNEAKING THROUGH THE BACKDOOR}

\section{(a) An ambivalent relationship}

At first glance, it is rather unsurprising that the analysed cases seem to support the premise introduced above ${ }^{72}$ - we observe the clear pattern that tribunals are utterly reluctant to refer directly to or even consider public interest argumentation. Sometimes, this hesitancy originates in the fact that the host State itself has contributed considerably to the situation it later claims to infringe its citizens' human rights or other public interest. In Azurix, e.g., the drinking water's infestation with bacteria was mostly due to decades of shortcomings in the reparation and renovation of Buenos Aires' water and sewage system when it was still run by the local government. ${ }^{73}$

In abstract terms, however, tribunals such as in Phoenix indeed acknowledge - in obiter dicta - that

'nobody would suggest that ICSID protection should be granted to investments made in violation of the most fundamental rules of protection of human rights, like investments made in pursuance of torture or genocide or in support of slavery or trafficking of human organs. ${ }^{74}$

Neer v. Mexico, supra n. 68.

See Metalclad Corporation v. United Mexican States, Award, 30 Aug. 2000, Case No. ARB(AF)/97/1.

See supra I.

See supra III. 1.

Phoenix Action Ltd. v. Czech Republic, Award, 15 Apr. 2009, (ICSID Case No. ARB/06/5), para. 78. 
Also, the Biwater award recognized that the outcome of the award was going to have an impact far beyond the bilateral relationship of the foreign investor and the host State. By stating that ' $[\mathrm{t}]$ here is an undoubtedly public interest in this arbitration, ${ }^{75}$ the tribunal accepted that the respective dispute left the private sphere of a mere controversy between two parties over contractual matters and touched upon challenges which concern third persons or even society as a whole. However, the tribunal halted here. Beyond such general acknowledgement, there is scarce if any argumentation to be found that expressly refers to the public interest when it comes to the actual legal analysis.

Hence, apart from rather hypothetical considerations investment tribunals apparently are very reluctant to take account of the public interest directly. Such reluctance, if not to say hostility, vis-à-vis public interest arguments cannot be explained by mere scepticism and ignorance. The roots must lie deeper than an alleged professional bias. ${ }^{76}$ Indeed, more and more eminent public international law scholars, many among them with a longstanding experience in the fields of human rights or international environmental law, become arbitrators in investment disputes, both under ICSID as well as NAFTA or other arbitration realms. As some scholars elucidate, the crux with public interest considerations lies in the question of the law applicable to an investment dispute. ${ }^{77}$ This, so some argue, further leads to the jurisdictional issue that the consent to arbitration is limited to the substance of the request for arbitration. ${ }^{78}$ Since international investment law - at least until now - lacks a solid theoretical foundation ${ }^{79}$ for the application of public international law norms beyond those enshrined in BITs, it is understandable that tribunals shy away from applying human rights or other public interest issues encapsulated in public international law norms, particularly if those may be asserted as defences against undisputable investor rights infringements. ${ }^{80}$

Thus one is tempted to ask: Why do the tribunals say one thing - explicitly brushing away public interest arguments by the host State or the amici - and actually do another - granting them entrance through the backdoor so to speak? One reason I have already given: The lack of doctrinal and theoretical foundation

75 Methanex Corporation v. United States of America, Decision on Petitions of Third Persons to Intervene as Amici Curiae, 15 Jan. 2001, para. 49; Biwater v. Tanzania, para. 358.

76 As argued by van Harten, supra n. 4, $152 \mathrm{ff}$.

77 P.M. Dupuy, 'Unification Rather than Fragmentation of International Law?' The Case of International Investment Law and Human Right Law', in P.M. Dupuy, F. Francioni and E.-U. Petersmann (eds.), Human Rights in Intemational Investment Law and Arbitration 45, 56 (Oxford U. Press 2009).

78 C. Reiner and C. Schreuer, 'Human Rights and Intermational Investment Arbitration', in P.M. Dupuy, F. Francioni and E.-U. Petersmann (eds.), Human Rights in International Investment Law and Arbitration 82 at 89 (Oxford U. Press 2009).

79 This is not to belittle the work of McLachlan, among others, vis-à-vis Art. 31 (3)(c) of the Vienna Convention on the Law of Treaties and systemic integration, cf. C. McLachlan, "The Principle of Systemic Integration and Art. 31(3)(C) of the Vienna Convention' (2005) 54 Int'l Comp. L. Q. 279-320 and id., 'Investment Treaties and General International Law' (2008) 57 Int'l Comp. L. Q. 361-401, who has focused on the doctrinal rather than the theoretical foundation, however. Also see B. Simma, 'Foreign Investment Arbitration: A Place for Human Rights?' 60 Int'l Comp. L. Q. 573-596 (2011).

80 However, see my attempt to remedy this in A. Kulick, supra n. 2. 
in the tribunals' argumentation ${ }^{81}$ for integrating human rights considerations into the investment realm and thus their fear to exceed their powers by going beyond what the parties have consented to.

This, however, merely explains why tribunals do not explicitly and directly consider public interest issues. It does not explain why they nonetheless do so implicitly and indirectly. In my opinion, the answer is quite simple: Because they see themselves confronted with deciding disputes involving questions of public interest they cannot disregard. They start to acknowledge that their role goes beyond being mere arbiters of private issues. Whether an investor can construct and operate a landfill, whether its rights are violated by a host State banning the export or import of chemical substances or whether a city's withdrawal of the concession to provide water services triggers the investor's claim to damages all constitute questions that are just different flipsides of the same coin: They foreshadow that, viewed from the opposite angle, the questions pertaining to the very same issue are also whether the investor is permitted to construct the landfill and how it operates it in the vicinity of a local community, whether a host State may ban the export or import of chemical substances potentially harmful to the environment or human health or whether an investor has fulfilled its obligations under the concession agreement to provide clean water and other water and water sewage services.

In the domestic realm, private contracts and disputes that exhibit such public interest relevance are usually embedded in a framework of public rules and regulations. Public procurement laws govern the tender, and shortcomings in providing the service or operating the site encounter responses by public law remedies, e.g. a fine or the rescission of the contract, usually administered by the executive. The Biwater Tribunal expressly recognizing the 'public interest' hence indicates the growing tendency in investment arbitration to acknowledge parallel needs in the international (investment) law realm, i.e. embedding the investor-host State dispute in a public law framework.

\section{(b) Backdoor or front door?}

Having thus made the point that investment arbitration tribunals in fact do care more about the public interest than they say expressly, I will now turn to how they factor it in doctrinally. The battlefield where the public interest actually unfolds its force is not (or not yet) to be found on the merits stage - here, as I have argued above, tribunals either decline to consider any public interest arguments or, as in Glamis, seek to ground their holding on well-established public international law standards the interpretation of which, however, appears to be influenced by public interest considerations.

However, the thrust of public interest considerations surfaces when it comes to what an investment dispute is eventually all about: compensation. I have argued

81 In contrast to the valuable attempts in the literature, investment arbitration tribunals so far have not made reference to Art. 31 (3)(c) VCLT as an avenue for interpretation of a BIT, also cf. supra n. 79. 
elsewhere ${ }^{82}$ that, in contrast to other international disputes, in investment arbitration, States care much less whether they are found to have violated international law. They do care first and foremost whether and how much compensation or damages they have to pay - particularly since even a lawful expropriation triggers the obligation to compensate.

That tribunals often follow the backdoor pattern is most obvious in the Biwater and Azurix cases. While the argumentations revolving around the right to water failed on the merits stage, the arbitrators then considerably reduced compensation (Azurix) or denied compensation at all (Biwater), basing their argumentation on topoi similar to those they had declined to adopt regarding the merits. ${ }^{83}$

In Biwater, the tribunal found that the investment's loss in value was not caused by the investor rights violations committed by the host State, for it was BGT's miscalculations that failed taking into account the adjustments necessary in the Dar es Salaam water system and the limits regarding licit increase of water prices. ${ }^{84}$ Similarly, the Azurix tribunal denied the investor recouping the USD 438.6 million canon payment because a reasonable businessman would have been in no position to expect recovering the entire canon given the limits of water price increase and the renovation necessary to guarantee a well-functioning and clean water system. ${ }^{85}$ In both cases the tribunals' arguments can be boiled down to the following: The investor is only entitled to compensation within the limits of what it can expect recouping when warranting a well-functioning, clean water system to affordable prices for everyone. Differently put, the amount of compensation is influenced and limited by the core principles of the right to water, i.e. the public interest.

However, the Glamis award is a good example that the indirect influence of human rights considerations begins to stretch beyond the confines of compensation. The Tribunal strictly harkening back to the Neer case of 1926 to determine the international minimum standard of treatment according to Article 1105 NAFTA appears to indirectly honour human rights and other public interest considerations as outlined in the Quechuan Non-Party Submission. ${ }^{86}$

It is not yet clear which avenue will establish as the choice of preference in international investment arbitration - the front door (i.e. dealing with public interest argumentation on the merits) or the back door (i.e. dealing with it on the level of compensation and damages). My conclusion assumes the latter.

Finally, a question to be asked but not to be answered fully here is whether such latter solution is preferable. Indeed, it appears that nowadays it has become common sense that investment disputes inhere public interest issues the tribunals are unable to fully neglect. However, the clandestine existence public interest argumentation seems to eke out at the present stage does neither do a favour to

\footnotetext{
82 See Kulick, supra n. 5, at 922.

83 See supra III. 2.

84 Biwater $v$. Tanzania, para. $786 \mathrm{ff}$.

85 Azurix v. Argentina, para. 426.

86 See supra III. 3.
} 
public interest nor to investment arbitration. It remains for future investment arbitration tribunals to be more courageous and undertake a more open task in identifying and considering public interest argumentation. Doctrinally, the most preferable place for this is, in my opinion, indeed the level of compensation and damages. ${ }^{87}$ Not only is this, as I have argued before, eventually the most crucial issue for both the investor and the host State. Reconciling the public interest with the investors' individual interest also should preferably translate into a balancing of both aspects rather than into the rather blunt instrument of either finding for an infringement of investor rights on the merits stage. From the outset, the Biwater approach hence is preferable to the solution chosen in Glamis. ${ }^{88}$ The best tool for such balancing would be proportionality. ${ }^{89}$ The result of the proportionality analysis would then impact the measuring of the amount of compensation and damages. ${ }^{90}$

87 See in this regard Liberti, supra n. 13, at 564 foreshadowing the balancing exercise.

88 See supra III. 3.

89 See Schill \& Kingsbury, supra n, 30 and recently A. Tanzi, 'On Balancing Foregin Investment Interests with Public Interests in Recent Arbitration Case Law in the Public Utilities Sector' 11 The L. Prac. Int'l Ct. Trib. 47 at 74 ff (2012). 
Arbitration Intermational, Volume 29 Issue 3 